\title{
Disorders of Thought and Mood: Connectivity, Transmission, and Modulation as Trinity of Biological Psychiatry
}

\author{
Gerhard Franz Walter \\ International Neuroscience Institute Hannover, Germany.
}

Corresponding Author: Gerhard Franz Walter, International Neuroscience Institute (INI) Rudolf-Pichlmayr-Str. 4 D-30625 Hannover / Germany.

Received date: February 01, 2022; Accepted date: February 15, 2022; Published date: February 21, 2022

Citation: Gerhard Franz Walter, (2022). Disorders of Thought and Mood: Connectivity, Transmission, and Modulation as Trinity of Biological Psychiatry. J. Neuroscience and Neurological Surgery. 11(3); DOI:10.31579/2578-8868/235

Copyrights: () 2022 Gerhard Franz Walter, This is an open-access article distributed under the terms of The Creative Commons Attribution License, which permits unrestricted use, distribution, and reproduction in any medium, provided the original author and source are credited

\begin{abstract}
Looking at the state of knowledge on the biological etiology of disorders of thought and mood as neuropathologist, I have encountered a broad range of associations between genetic and epigenetic findings, various relations to the contemporary knowledge on the importance of connectivity, neurotransmission, and modulation by neuropeptides, but nothing appeared sufficiently specific, so far. Taking disorders such as schizophrenia, anxiety, or autisms as examples I have critically reviewed and commented seven main hypotheses on the etiology of mental disorders. The often mutually exclusive or contradictory hypotheses are each fascinating in their highly sophisticated approaches, but remain altogether confusing; is there anything not responsible for disorders of thought and mood? If illnesses are poorly understood, they are poorly treated.
\end{abstract}

Key words: connectomics; neurotransmitters; neuropeptides; schizophrenia; autism; anxiety

\section{Introduction}

My theory is that the human species was crazy from the very first and that civilization and culture are only enhancing man's insanity.

Isaac Bashevis Singer, Nobel Laureate for Literature. A Tale of Two Sisters (short story), 1968. In: The Collected Stories, 1982 [1].

The roots of German neuropathology consolidated not in neurological clinics but in research institutes of neurology, which were not headed by pathologists but by neuropsychiatrists, then neurology and psychiatry not being separated fields. Alois Alzheimer was neuropsychiatrist and neuropathologist at once, only to mention in an exemplary manner a researcher who gained prominence even in a broad lay public. The primary motive of these searching neuropsychiatrists was to detect the morphological cause of psychoses by means of the then modern cellular pathology rather than to regard psychoses as pure functional disorders of the 'psyche'. In a brain autopsy of a patient with dementia who had reported him 'to have lost herself', Alois Alzheimer described in 1906 a typical cellular morphology, 'a peculiar disease of the cortex' [2], which led eventually to the assignment of Alzheimer disease to the field of neurology.

This appeared more difficult for mental diseases sensu stricto. In 1896, Emil Kraepelin formulated the concept of dementia praecox [3], which was further developed by Eugen Bleuler to the concept of schizophrenia [4], a hallmark disease still today assigned to the field of psychiatry, thus, in literal meaning illnesses of a non-substantial soul.
Being neuropathologist myself and therefore an outsider of psychiatry sensu stricto, I was searching for contemporary substantial biological knowledge on the etiology of disorders of thought and mood. If I put forward connectivity, transmission and modulation as trinity of biological psychiatry, then I am well aware that we all know in principle how neurons talk to each other, being intertwined by connecting extensions such as neurites and dendrites, transmitting electrical information induced by polarization and depolarization of the neuron invoking an electrical impulse in form of a saltatory induction that skips from node to node down the full length of an axon, synaptic biochemical transmission involving the release of neurotransmitters - biogenic amines - from the pre-synaptic neuron binding to specific post-synaptic receptors, and eventually a modulation of the information by neuropeptides oligopeptides - functioning as neuromodulators. All these physiological effects are genetically determined and epigenetically adapted, but we still do not fully understand how they influence disorders of thought and mood.

\section{Methods}

For the present review, I have selected some 'model' illnesses such as schizophrenia or autism, first, to analyze current methodical approaches and, second, to comment seven contemporary hypotheses on the available biological evidence on connectivity, transmission and/or modulation. 


\section{Connectivity}

The human brain is a complex network of anatomically segregated regions interconnected by white matter pathways, known as the human connectome. Network studies of large-scale brain connectivity have begun to reveal attributes that promote the segregation and integration of neural information: communities and hubs. Network communities are sets of regions that are strongly interconnected among each other, while connections between members of different communities are less dense. The clustered connectivity of network communities supports functional segregation and specialization. Network hubs link communities to one another and ensure efficient communication and information integration [5].

Connectomics has created a deeper understanding of the overall organization of brain wiring, its relation to healthy brain function and human cognition, and conversely, how brain disorders may arise from abnormal brain network wiring. This abnormal wiring may result in hard wiring during neurodevelopment, e.g., migration disorders, and changing wiring due to neural plasticity or disruption. To give a rough and admittedly simplified idea, super- and subconnectivity possibly being a consequence of inborn hard wiring variations, mal- and disconnectivity possibly due to acquired wiring disorders: superconnectivity (savants), subconnectivity (autism), malconnectivity (schizophrenia), subconnectivity (autism), mation).
disconnectivity (neurodegeneration
Variations of connectivity involving distributed brain regions have gained interest. In malconnectivity, postmortem and neuroimaging studies delineated changes in brain structure and volume due to reduction of neuritic processes such as dendrites and synapses rather than loss of neuronal or glial cell bodies. Schizophrenia, for instance, was attributed to impaired connectivity $[6,7]$.

Autism is a neurodevelopmental disorder that is characterized by impaired social interactions and aberrant basic information processing. Aberrant brain connectivity patterns already present at the early stages of brain development have indeed been hypothesized to be a key underpinning of autism. Widespread cortical subconnectivity, local superconnectivity, and mixed results suggest disrupted brain connectivity as a potential neural signature of autism. Autism is associated with the autism susceptibility candidate 2 gene [8,9]. A highlighted group are autistic people with savant-syndrome who show heightened sensory sensitivity, obsessional behaviors, technical/spatial abilities, systemizing, and a different approach to task learning, all key aspects in defining the savant profile with superconnected cortical areas distinct from autism alone $[10,11]$. Famous persons with savant-syndrome are Stephen Wiltshire and Laurence Kim Peek. Stephen Wiltshire is autistic and is known for his ability to draw a landscape from memory after seeing it just once (figure 1)

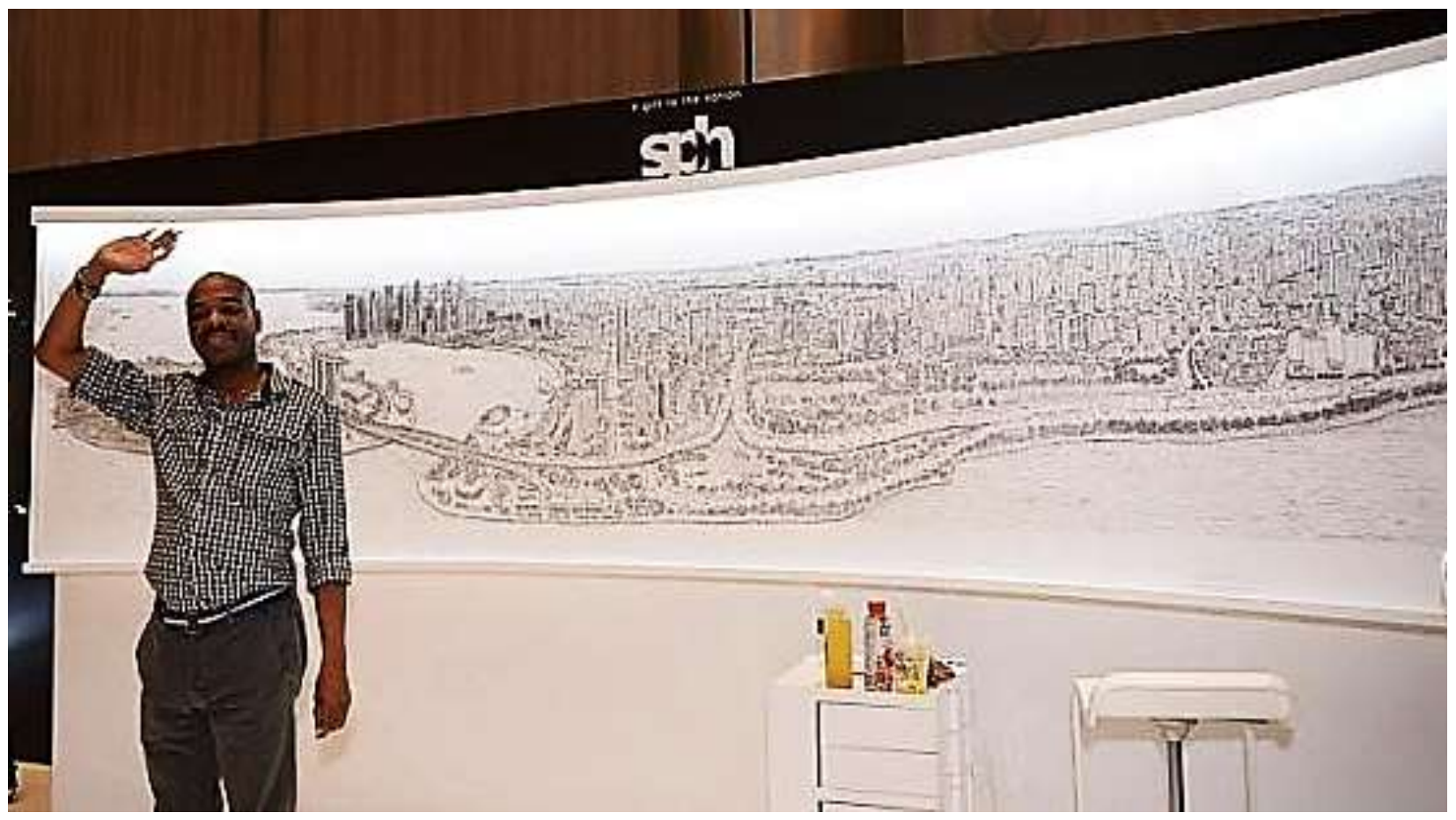

Figure 1: In July 2014, Wiltshire drew an aerial panorama of the Singapore skyline from memory after a brief helicopter ride, taking five days to complete the $1 \times 4 \mathrm{~m}$ artwork.

Laurence Kim Peek who was considered a 'mega-savant' because he was a genius on at least 15 different subjects, from history to sport. Peek had an extraordinary memory. According to his own statement, he knew the content of 12,000 books almost memorable. It was enough if he had read the book just once. Each side of a book, he needed to see only about seven seconds to remember the full content. Peek had neurodevelopmental brain damage but was not autistic. MRI examinations of Peek's brain showed an enlargement of the two hemispheres and an agenesis of the corpus callosum. In addition, an unusually shaped and reduced cerebellum was detected [12]. Synesthesia can also be seen as connectivity variation; obviously, synesthesia in autism is linked to those with savant abilities rather than autism per se [13].

\section{Hypothesis 1: The 'revolutionary' single gene}

It is proposed that the mutation of a single 'revolutionary' gene has caused the speciation event, the remarkable growth of the human brain in comparison to the non-human primate brains, and the enlarged connectivity of the brain cortex. If only one mitosis is added to the cell generations of cytogenesis, the number of neurons produced doubles. The size difference of the brains between Australopithecus and Homo erectus 
can be explained by only one additional mitosis in some parts of the cerebral hemispheres. With one more mitosis in all parts of the hemispheres, the size of the modern brain of Homo sapiens would be reached $[14,15]$. Further, there was a specific proliferation in those cortical areas of the dominant hemisphere responsible for language. We know since more than 150 years from Paul Broca's case on motor aphasia and his conclusion on the 'siège de la faculté du langue' [16], and since Carl Wernicke's description 13 years later of the sensoric part of the language centers in the left hemisphere [17] that these centers are lateralized in the cerebral cortex, though there is no doubt that language is a bihemispheric phenomenon [18-20]. Lateralization causing cerebral dominance, handedness and language has been linked to the same single 'revolutionary' gene responsible also for schizophrenia, the latter regarded as the prize that Homo sapiens pays for language [21].

\section{Comments}

First, a comment on morphological findings: It seems, that a larger brain size may once have been vitally important for human survival, and that the trend toward increased brain size, which marked the first 2 to 3 million years of human evolution, had induced that 'culture and the benevolence of social life have taken place of nimble wits as an insurance policy against extinction' $[22,23]$. Does brain size have any influence at all on schizophrenia? It was reported that schizophrenic patients with smaller brain size and intracranial volumes were more likely to be unaware of their symptoms than patients who were aware, the latter group having about the same brain size as healthy comparison subjects [24]. A reduction of the size of the superior temporal gyrus occurring particularly in schizophrenic females was described [25] whereas others report a significantly smaller left temporal lobe volume in male patients than in male comparison subjects, but no significant difference in female patients and female comparison subjects [26]. However, these observations are very unspecific regarding the broad range of brain size in healthy people.

Neuropathological findings remain unspecific, so far [27]. Indeed, in schizophrenia, there is a left-sided preference of the pathology: loss of structures of the left medial temporal lobe including hippocampus, thinning of the left parahippocampal gyrus and superior temporal gyrus, reduction of the length of the left Sylvian fissure, and enlargement of the left lateral ventricle. If language centers were concentrated in the dominant hemisphere by a genetic high-connectivity process of hemispheric specialization, bihemispheric language had to evolve under constraints on callosal transmission out of necessity for a well-functioning connection between both hemispheres. Indeed, looking at neuropathology, the callosal size may be markedly reduced in schizophrenia [28], and its decrease perhaps may vary directly with the length of illness indicating the progression of the process [29].

However, I must admit that the difficulty to find a distinct morphological pattern exclusive of psychoses led for decennia to a regrettable neglect of this field of research among my fellow neuropathologists, even being regarded as the 'graveyard of neuropathologists' [30]. In short, I would doubt a neuropathologist's diagnosis of schizophrenia or any other psychosis alone from the macroscopic findings of a brain autopsy.

Second, a comment on the monogenic theory: If schizophrenia is independent of the environment, it should be a genetic condition that preceded the diaspora of modern humankind, since schizophrenia occurs in human populations, including people from different cultures and even isolated regions such as in Australian aboriginal population, in the African Bantu, and in tribes of central Borneo. The initial causative mutation of the 'revolutionary' gene might indeed have occurred early in evolution. But what does it mean? Are we all prone to schizophrenia?

Not only language but also handedness may be a typical human peculiarity. Mixed-handedness may indeed indicate susceptibility for schizophrenia [31]. The monogenic hypothesis would mean that cerebral dominance, handedness and language are inextricably and causally linked to each other and to a single gene, the same gene being responsible for schizophrenia. However, there is no conclusive evidence for the genetic event - the 'big bang' [32] - that defined our species and is responsible for language and the origin of psychoses.

Third, a comment on autism: The autism susceptibility candidate 2 gene is another interesting gene in neurodevelopment of Homo sapiens, but it is associated to a wide range of neuropsychological disorders such as autism spectrum disorders, intellectual disability, epilepsy and schizophrenia, thus, not the single all-explaining gene. The AUTS2 gene is not specific. It has been shown to be involved in multiple neurodevelopmental processes; it acts as a key transcriptional regulator in neurodevelopment, it participates in cerebral corticogenesis, including neuronal migration and neuritogenesis, through the control of cytoskeletal rearrangements [33].

Based on the assumption of a universal neurodevelopmental model of psychosis, studies of minors indicated that developmental aspects may play a crucial role in the prevalence and appraisal of diagnostically relevant positive psychotic symptoms in their full-blown and subthreshold forms, including neurobiogenetic and other risk factors [34].

\section{Hypothesis 2: The polygenic superabundance}

Let us look again at schizophrenia as model: A multicenter linkage study of schizophrenia candidate regions on chromosomes 5q, 6q, 10p, and 13q collaboratively evaluated respective data from the literature [35]. The data most supportive for linkage to schizophrenia were from chromosome $6 \mathrm{q}$. By another group, the transcription factor activator protein 2 gene (AP-2 gene) on chromosome $6 \mathrm{p}$ was discussed as a candidate for the localization of a schizophrenia gene [36]. In the Irish study of high-density schizophrenia families, linkage to chromosomes $5 \mathrm{q}, 6 \mathrm{p}, 8 \mathrm{p}$, and $10 \mathrm{p}$ was looked for, localizing a putative susceptibility gene for schizophrenia in the $8 \mathrm{p} 22-8 \mathrm{p} 21$ region. No association was found for the other chromosomes, including the possible candidate chromosome $6 p$ [37]. Another major susceptibility locus was suspected on chromosome 1q [38]. To date, using the polygenic risk score, in the genome-wide association study (GWAS) of schizophrenia, the impressive number of 108 schizophrenia-associated loci were identified. [39].

\section{Comment}

Tim Crow, the most expressive representative of the monogenic theory, describes the situation as "polygenes of vanishingly small effect or multiple false positives' or 'the emperors of the schizophrenia polygene have no clothes' $[40,41]$. In the search for the causative schizophrenia gene, almost no chromosome was and is left out, indeed. But what does it mean? Too many loci to give an indisputable explanation. Do all schizophrenics suffer from 108 mutated loci (of course not), or from different combinations of these loci and of how many different combinations? It might be a valuable approach to investigate all schizophrenics for all 108 loci and to exclude - for a starting point - all associated loci which do not appear in all patients. Then, several candidate regions, some loci might remain, which can be identified in a replicable manner in all patients.

\section{Hypothesis 3: The epigenetic influence}

Are psychoses acquired disorders? It is hypothesized that psychoses have to be regarded as multifactorial and reflect an interaction between (epi)genetic vulnerability and environmental contributors. Epigenetic misregulation of the genome, manifesting as molecular 'scars' [42], caused by prenatal or postnatal environmental effects may affect vulnerable CNS pathways. Non-genetic environmental risk factors such as pregnancy and birth complications, childhood trauma, migration, social isolation, urbanicity, viruses, ethanol, nutritional deficiency and 
substance abuse, alone and in combination, acting at a number of levels over time, were thought to influence the individual's likelihood to develop schizophrenia [43-46].

\section{Comment}

Certain risk loci may influence stochastic variation in gene expression through epigenetic marks, including cross-talk between DNA methylation and histone modification processes highlighting the intricate interaction between genetic and epigenetic control of neurodevelopmental trajectories. However, there is quite a considerable amount of most heterogenous putative environmental risks; if we have escaped the risk of birth complications, then we might undergo the risk of urbanicity, and if we fortunately live in a rural area, we might become victims of ethanol abuse. In summary, almost every environmental condition might be made responsible to develop psychosis, but no substantive environmental precipitant can be pinned. The use of novel hybrid models integrating molecular genetic risk markers, as well as the use of twin studies in epigenetics might prove to significantly enhance research in a postGWAS-era [47].

\section{Hypothesis 4: Gender differences in connectivity}

It was suggested that a gene for asymmetry is present in homologous form on the $\mathrm{X}$ and $\mathrm{Y}$ chromosomes explaining the sex difference in age of onset of schizophrenia as well as the sex differences in morphological brain changes, of particular interest being the regions Xq21.3/Yp11.2 with regard to schizophrenia and handedness, further, that an X-Y homologous gene would have relevance to the speciation theory, and that a translocation from the $\mathrm{X}$ to the $\mathrm{Y}$ chromosome linked to psychosis may provide an advantage to male in the competition for females, thus not being rapidly selected out of the population [48].

By means of neuroimaging, effects of age, sex and psychosis symptoms on thalamocortical functional connectivity in youth were characterized. Females showed greater connectivity between multiple thalamic nuclear groups and the visual cortex compared to males, while males showed greater connectivity with the inferior frontal and orbitofrontal cortices. Youth with psychosis spectrum symptoms showed a subtle decrease in thalamic connectivity with the premotor and prefrontal cortices [49].

\section{Comment}

The genetic evidence is heterogenous; neuroimaging provides some indication for gender differences. Some studies have focused on the characterization of clinical phenomenology regarding gender in population at high-risk of psychosis suggesting that differences between men and women in the expression of psychosis extend across a continuum, from the subclinical forms of illness to the debut of psychosis. However, a comprehensive critical review concluded that the small number of studies and their significant methodological and clinical limitations do not allow for firm conclusions [50].

\section{Transmission}

As examples, I will confine myself to the catecholamineneurotransmitters dopamine and norepinephrine/epinephrine, and to the indolamine-neurotransmitter serotonin.

The capacity to generate heritable phenotypic variation, the 'evolvability' [51], of dopamine systems has been instrumental to adapt vertebrates to nearly all the possible environments [52]. Dopamine is associated with memory and, as part of the brain's reward system, with pleasurable sensations. Subcortical dopaminergic dysfunction is involved in psychotic symptoms. Patients with schizophrenia showed increased presynaptic dopamine function in the associative striatum, rather than the limbic striatum as previously presumed [53]. Hallucinations, a central symptom of psychotic disorders, are attributed to excessive dopamine in the brain. A causal role for dopamine-dependent striatal circuits in hallucination-like perception is discussed [54]. So, dopamine is not only a 'feel-good' neurotransmitter. Psychosis is now widely hypothesized to involve neural networks beyond the classical dopaminergic mesolimbic pathway, including serotonin and glutamate systems as well [55].

What is the role of epinephrine and norepinephrine? Confronted with frequently occurring post-traumatic stress disorder in soldiers during the First World War, in 1915, Walter B. Cannon described the 'fight-orflight' response as immediate physical and mental adaptation in hazardous situations. The brain reacts to threats by sending impulses via the sympathetic nervous system to the adrenal medulla which - enhanced by a positive feed-back between adrenal medulla and the sympathetic nervous system - secretes catecholamines, especially norepinephrine and epinephrine. The cardiac output and the respiratory rate are enhanced, which enables the threated person for confrontation or escape [56]. This sequence was expanded to 'freeze-flight-fight-or-fright', freeze characterized by increased attention (hypervigilance) and motionlessness in the hope to be overlooked, and fear characterized by anxiety and the intention to play dead [57]. This latter behavior was further expanded into 'freeze-flight-fight-fright-or-faint' with fainting as ultimate response [58]. There might be a gender difference in responses to stress, symbolized by the term 'tend-and-befriend' as a potential response of women on stress: protect the offspring (tend) and offer friendship (befriend) [59]. Does anxiety induce psychosis?

Since the earliest reports of mankind, anxiety is closely related to the idea of more or less unpredictable outside forces, 'gods', influencing life, culminating in an almighty and revengeful god who has been insulted by the people disregarding his strict commandments. In my view, this idea has much to do with the person of the almost almighty father in the extended ancient family, the chief of the clan, very similar to the role of the alpha-individual in the animal kingdom. Traditionally, the father is not perceived as mild and forgiving, but as someone who creates a sense of guilt and anxiety. There is a continuity to the mighty 'redoubtable king' as 'father of the nation', and to the almighty 'god-father' in heaven expecting god-fearing believers. But is this mighty force indeed outside? Is it not imaginary and inside, very much like Sigmund Freud's 'überich'?

Beyond all doubt anxiety is not an exclusive human attribute and it is not only related to stress-induced secretion of the catecholamines epinephrin and norepinephrine, but also serotonin may play a crucial role. Serotonin is influencing mood, cognition, reward and memory. A polymorphism of the serotonin transporter gene (SERT gene) was tentatively associated with schizophrenia and unipolar depression but not with bipolar disorder [60]. In animal experiments, it has been shown that serotonin (5hydroxytryptamine, 5-HT) influences emotional processes, e.g., anxiety in 5-HT $\mathrm{HA}_{1 \mathrm{~A}}$ receptor mutant mice [61], and anxiety and increased 5-HT $\mathrm{H}_{1 \mathrm{~A}}$ receptor response in neural cell adhesion molecule (NCAM) null mutant mice [62]. An increased cortical 5-HT $1 \mathrm{~A}$ receptor is discussed regarding the malconnectivity hypothesis of schizophrenia, also since in schizophrenia brains the expression of the embryonic form of NCAM is decreased [63].

\section{Hypothesis 5: Traits or symptoms}

In mental disorders, the border between health and disease is blurred. Conceptually, schizotypy is characterized by the presence of schizophrenic-like thought patterns and/or belief systems in the absence of psychosis, including traits such as magical thinking, unusual perceptual experiences, and paranormal beliefs [64]. If there is an inborn disposition to believe in unpredictable outside forces, then atypical connection of brain centers might relativize these sensations to cope situations of daily life. 
Atypical brain lateralization may play a certain role, being evident in people who are highly creative and in people who have high levels of schizotypal traits $[65,66]$. Anxiety and affective symptoms are prominent features of schizophrenia which are often present in the prodromal phase of the illness [67]. Is schizophrenia an anxiety disorder? Genius and madness have long been thought to be intimately entwined. When looking at paintings by schizophrenic artists, the proximity of genius and madness seems quite believable (figure 2).

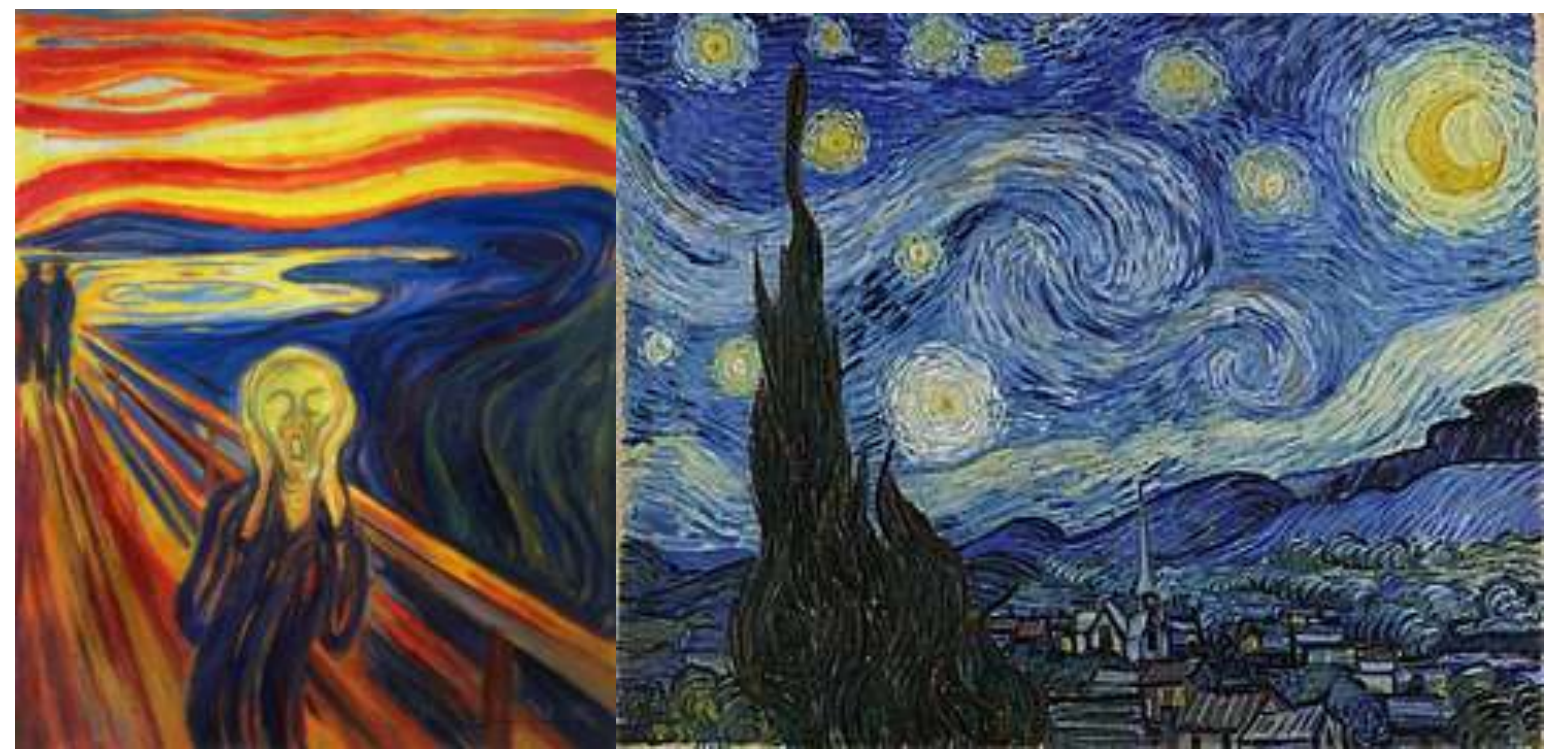

Figure 2: Edvard Munch 'The Scream' (1893), National Gallery Oslo (left). Vincent van Gogh 'The Starry Night' (1889), Museum of Modern Art New York (right).

The Norwegian painter Edvard Munch wrote in his notes: 'Illness, madness and death were the black angels that watched over my cradle and have since followed me through life'. His childhood was overshadowed by illness, bereavement, and the dread of inheriting a mental condition that ran in the family $[68,69]$. Illness-related motifs form a significant part of his pictorial world such as in the transformation of a hallucination into his famous artwork "The Scream" from 1893, widely identified with "Angst".

The Dutch painter Vincent van Gogh is said to have found rest in the Saint-Paul-de-Mausole psychiatric hospital in Saint-Rémy from his anxiety attacks when, in the autumn of 1889 , he painted "The Starry Night”. Many different diagnoses have been made over the past 130 years. From absinthe-induced temporal lobe epilepsy, schizophrenia, interictal personality disorder via bipolar disorder, and cycloid psychosis [70, 71].

\section{Comment}

The idea to be somehow born to genius, madness, and simultaneously crime, in persons being in a permanent psychological state of emergency, was brought forward in 1872 by Cesare Lombroso in his book 'Genio e follia', to which he gave a citation from Hamlet as dedication: 'Alla pazzia dei grandi presta grande attenzione - Madness in great ones must not unwatch'd go' [72]. Cesare Lombroso was Professor of Legal Medicine and of Psychiatry; he is considered to be the founder of the socalled Positive School of Criminology, which is oriented towards criminal anthropology and ensured that in the 19th century more and more scientifically trained specialists, above all physicians, but also biologists and anthropologists, dealt with the topic of crime and its relation to human biology, especially to disorders of thought and mood.

In psychoses, heritability and familial transmission have been known for several decades; however, despite the clear evidence for a genetic component, it has been very difficult to pinpoint specific causative genes. There is only restricted genetic evidence for interdependencies between neurotransmitters and the above-mentioned neural cell adhesion molecule
(NCAM) which is important for neurodevelopment. NCAM is involved not only in the adhesion between neural cells, but also in neuronal migration, neuritic outgrowth and fasciculation, and in synaptic plasticity. In an experimental model, NCAM null mutant knockout mice developed an intermale aggressive and at the same time anxious behavior combined with an increased 5-HT $\mathrm{H}_{1 \mathrm{~A}}$ receptor response, suggesting a functional change in the serotonergic system [73]. Interestingly, the transgenic expression of NCAM reconstitutes normal behavior in these knockout mice [74]. Is this a biological model exemplifying an inescapable genetic program, in fact genetic prison, where like in this experimental setting emotions can arbitrarily be switched on and switched off?

Furthermore, NCAM knockout mice have documented deficits in neural migration and display increased lateral ventricle size [75]. There is a decreased expression of the embryonic form of NCAM in patients with schizophrenia [76], and elevated concentration of NCAM variable alternative spliced exon isoforms are found in schizophrenia, but not in bipolar disorder, nor in depression or in normal control subjects [77].

\section{Modulation}

Modulation by neuropeptides is the third component to be put forward next to connectivity and neurotransmission.

In 1902, the demonstration by William Maddock Bayliss and Ernest Starling that acid liberates a chemical messenger from the cells of the duodenal and jejunal mucosa and that this, by traveling through the blood, excites the pancreas to secrete, revolutionized physiology. They called this messenger secretin and coined the term hormone to describe specific chemicals that stimulate an organ at a distance from the chemical's site of origin [78]. Secretin was the very first detected neuropeptide. In the meantime, we know the terminology 'gut-brain axis' which points out a bidirectional relationship between the gastrointestinal system and the central nervous system. On the one hand, brain regulates movements and functions of the gastrointestinal tract (sensory and secretion), for instance, through the hypothalamic pituitary adrenal axis by mediating stress 
responses impact on the gut functions. On the other hand, brain functions such as cognition, behavior and even nociception are under the influence of the gastrointestinal system. About 40 years ago I was investigating the distribution of various neuropeptide-producing cells in the gut by means of electron microscopy and immunofluorescence [79], among these also secretin (figure $3 a$ and $3 b$ ).

Since then, there is large evidence pointing to critical roles for neuropeptides in modulating neurobiological responses to a multitude of

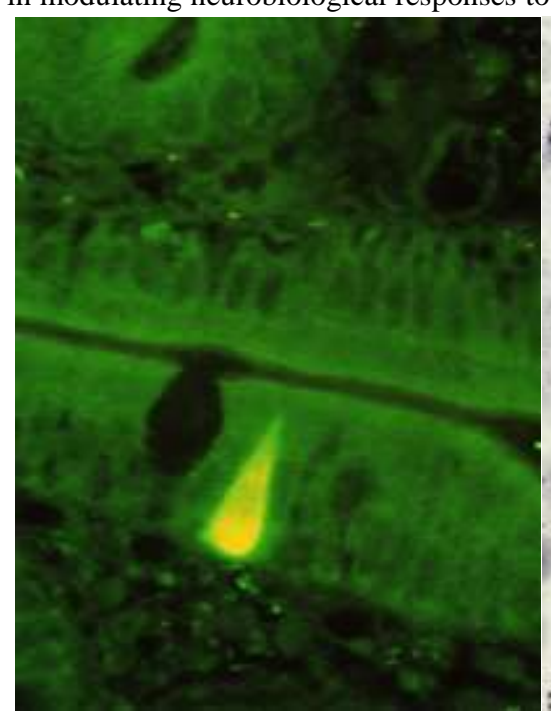

activities. There are now over 100 known neuropeptides, and probably many more yet to be identified from the over 1000 predicted peptides encoded in the genome [80]. Examples first identified within the gastrointestinal tract are vasoactive intestinal peptide (VIP) and gastrin, examples first identified within the nervous system are neurotensin and enkephalin. Among the almost countless neuropeptides I would like to mention neuropeptide Y (NPY) because it has been identified as the most abundant neuropeptide present in the central nervous system (figure $3 \mathrm{c}$ ).

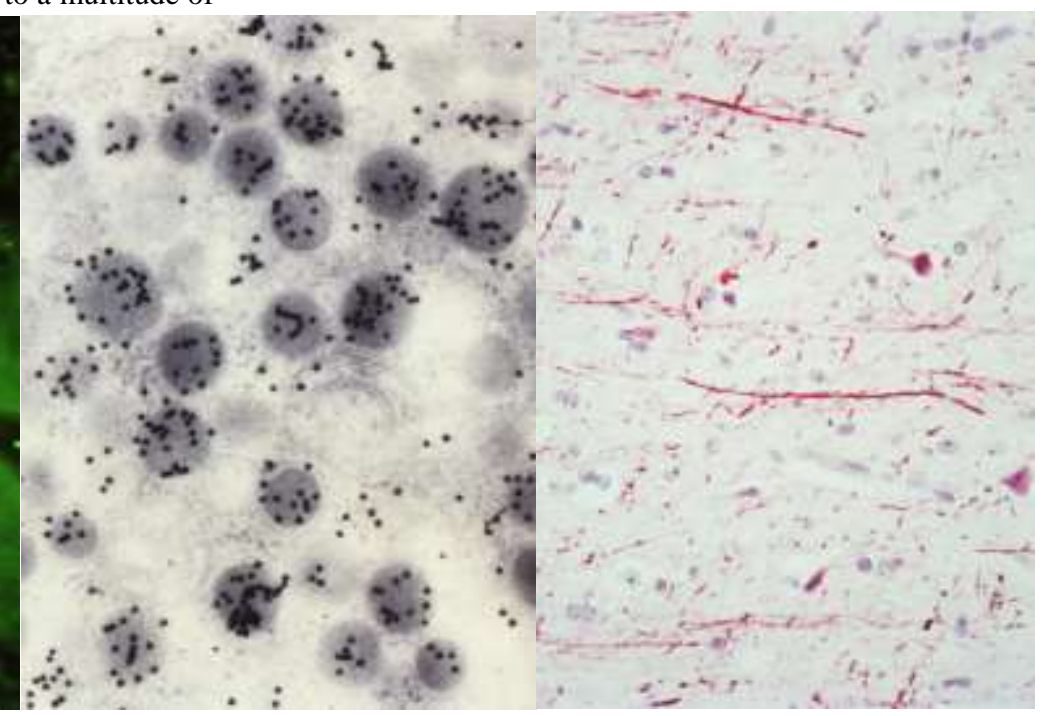

Figure 3: a. Secretin-producing cell (yellow) in the duodenum, immunofluorescence. b. Intracellular secretory granules containing secretin marked by small colloidal gold-particles, immunogold-transmission electron microscopy. c. Neuropeptide Y-fibers (red) in hypothalamic tissue, APAAPimmunohistochemistry.

The emergence of the microbiota (the trillions of microorganisms within and on our bodies) as one of the key regulators of gut-brain function has led to the appreciation of the importance of a distinct microbiota-gut-brain axis. Stress may significantly impact the microbiota-gut-brain axis at all stages of life [81]. The in my view best analysis of the microbiota-gutbrain axis available was presented by Peter Holzer: Currently, six particular modes of a neuropeptide link are emerging. (i) Neuropeptides and neurotransmitters contribute to the mutual microbiota-host interaction. (ii) The synthesis of neuroactive peptides is influenced by microbial control of the availability of amino acids. (iii) The activity of neuropeptides is tempered by microbiota-dependent autoantibodies. (iv) Peptide signaling between periphery and brain is modified by a regulatory action of the gut microbiota on the blood-brain barrier. (v) Within the brain, gut hormones released under the influence of the gut microbiota turn into neuropeptides that regulate multiple aspects of brain activity. (vi) Cerebral neuropeptides participate in the molecular, behavioral, and autonomic alterations which the brain undergoes in response to signals from the gut microbiota [82].

It is increasingly apparent that the gut-brain axis plays a critical role in brain and mental health. With focus on autism spectrum disorder, psychotic disorders, stress and anxiety disorders, depression, Alzheimer disease, and Parkinson disease, the comorbidity between inflammatory bowel disorder and mental health disorders was investigated. Interrogating the role of sex - modifying the relationship between gut and immune system as well as between brain and behavior - may lead to better understanding of the etiology of mental disorders [83].

Hypothesis 6: Microbiota-gut-brain axis as pathway for inflammatory disorders of thought and mood
Psychoses were suspected to be neuroimmune diseases, possibly triggered by infectious agents which act along the gut-brain axis.

The gut microbiota and the brain interact with each other through multiple bidirectional signaling pathways in which neuropeptides play potentially important mediator roles. Environmental and infectious agents, intestinal neuromodulators, sensory vagal fibers, cytokines, and essential metabolites convey information to the central nervous system about the intestinal state. Conversely, the hypothalamic-pituitary-adrenal axis, the central nervous system regulatory areas of satiety, and neuropeptides released from sensory nerve fibers affect the gut microbiota composition directly or through nutrient availability. Such interactions might influence the pathogenesis of disorders in which inflammation is implicated, such as mood disorder, autism-spectrum disorders, attention-deficit hypersensitivity disorder, multiple sclerosis, and obesity [84].

\section{Comment}

The neuroimmune hypothesis of schizophrenia was based on studies suggesting that neuroinflammatory processes may play a role in schizophrenia pathogenesis, at least in a subgroup of patients. Alterations in both pro- and anti-inflammatory molecules in the central nervous system and in peripheral tissues may occur and might correlate with schizophrenia symptoms $[85,86]$. To ask it in a provocative manner: Is psychosis contagious? Somehow as we thought that peptic ulcers come on as result of physiological stress, or as we think now by infection with the bacterium Helicobacter pylori.

\section{Hypothesis 7: The anxiolytic neuropeptide}

There is an interesting research parallelism with Walter B. Cannon's description of the above mentioned 'fight-or-flight' response. War veterans who have experienced shocking or dangerous events may 
develop a post-traumatic stress disorder (PTSD). In 2006, it was shown that a significant group difference in plasma NPY was observed, reflecting higher NPY levels in exposed veterans without PTSD than in nonexposed, but comparable levels in veterans with current PTSD [87]. Is NPY an insurance against anxiety?

\section{Comment}

NPY is expressed in particular neurons of the brainstem, hypothalamus and limbic system, which explains why NPY has an impact on stressrelated changes in emotional-affective behavior as well as on stress coping by reducing anxiety. Thus, NPY indeed is an anxiolytic neuropeptide preventing the negative consequences of stress. But polymorphisms of the NPY gene are predictive of impaired stress processing and increased risk of neuropsychiatric diseases [88, 89].

\section{Conclusion}

Since the causes of dementia praecox still are completely obscure, an effective combatting of the illness is at this time not possible. Treatment is of necessity limited to the lessening of illness symptoms.

Emil Kraepelin, 1921 [90]

To date, 100 years after Kraepelin's remark on dementia praecox one gets the impression that we still wander around obscure surroundings. On the cellular level our knowledge is still quite limited about what happens when cells touch and talk to each other. How exactly functions neural recognition in a plastic nervous system under 'normal' conditions and how when disorders of thought and mood occur? I do not have the impression that we already understand the complex interaction of connected neurons, the transmission and modulation of information between neurons and specialized brain centers, the epigenetic influence of most various environmental factors, the blurred border between physiological variations of behavior on the one side and psychopathology on the other side. If illnesses are poorly understood, they are poorly treated.

What plays the crucial role for the uniqueness of the human brain? Is the uniqueness of humankind our inevitable determination within nature, the product of genetics, possibly an exclusive 'true' human gene? Does man's insanity exist from the very first as Isaac Bashevis Singer ironically suspects in the above cited short story? Or is it not inborn nature, but the effect of nurture in Sir Francis Galton's definition, of human cultural behavior, of an early in life acquired human 'Prägung' such as proposed by Nobel laureate Konrad Lorenz, an impregnation impressed in the infant brain? Or a combination of both?

Of all above mentioned hypotheses on the origin of psychoses in general and of schizophrenia in particular, Tim Crow's hypothesis on schizophrenia as the prize that homo sapiens pays for language [21] is quite seductive and fascinating whereas all other hypotheses are indeed fascinating but still confusing. On the grounds of firm data at my disposition, I was not able to falsify this hypothesis of the human gene per se associated with our faculty of language and the occurrence of disorders of thought and mood. Some of these disorders may even not be illnesses but variations within our species. However, I prefer Tim Crow's hypothesis for its poetic thought. If we regard languages - all human languages in their diversities - as the outrageous works of art that they are in their everyday realism, in their scientific abstraction, in their metaphoric and poetic imagery, then the prize involved - psychoses being 'illnesses' of often particularly gifted people - would not be too dearly paid.

\section{Statement of Ethics}

Ethical approval was not required for this study in accordance with national guidelines.

\section{Disclosure Statement}

The author has no relevant financial or non-financial interests to disclose. The author has no conflicts of interest to declare that are relevant to the content of this article.

\section{Funding Sources Statement}

This study did not receive any funding or grant support.

\section{References}

1. Singer IB. The Collected Stories. New York: Farrar Straus Giroux, 1982. ISBN 13:9780374126315.

2. Alzheimer A. Über eine eigenartige Erkrankung der Hirnrinde. Vortrag auf der 37. Versammlung der südwestdeutschen Irrenärzte in Tübingen, 1906.

3. Kraepelin E. Psychiatrie: Ein Lehrbuch für Studirende und Aerzte, 5. Auflage. Leipzig: Johann Ambrosius Barth, 1896.

4. Bleuler E. Dementia praecox oder Gruppe der Schizophrenien. In: Aschaffenburg G, ed. Handbuch der Psychiatrie: Spezieller Teil 4. Leipzig - Wien: Franz Deuticke, 1911.

5. Sporns O. Network attributes for segregation and integration in the human brain. Curr Opin Neurobiol. 2013 Apr;23(2):162-71. doi: 10.1016/j.conb.2012.11.015. Epub 2013 Jan 4. PMID: 23294553.

6. Crow TJ. Schizophrenia as a transcallosal misconnection syndrome. Schizophr Res. 1998 Mar 10;30(2):111-4. doi: 10.1016/s0920-9964(97)00139-4. PMID: 9549773.

7. Friston K, Brown HR, Siemerkus J, Stephan KE. The dysconnection hypothesis (2016). Schizophr Res. 2016 Oct;176(2-3):83-94. doi: 10.1016/j.schres.2016.07.014. Epub 2016 Jul 20. PMID: 27450778; PMCID: PMC5147460.

8. Boersma M, Kemner C, de Reus MA, Collin G, Snijders TM, Hofman D, Buitelaar JK, Stam CJ, van den Heuvel MP. Disrupted functional brain networks in autistic toddlers. Brain Connect. 2013;3(1):41-9. doi: 10.1089/brain.2012.0127. PMID: 23259692.

9. Maximo JO, Cadena EJ, Kana RK. The implications of brain connectivity in the neuropsychology of autism. Neuropsychol Rev. 2014 Mar;24(1):16-31. doi: 10.1007/s11065-014-9250-0. Epub 2014 Feb 5. PMID: 24496901; PMCID: PMC4059500.]

10. Treffert DA. Savant syndrome: realities, myths and misconceptions. J Autism Dev Disord. 2014 Mar;44(3):564-71. doi: 10.1007/s10803-013-1906-8. PMID: 23918440.

11. Hughes JEA, Ward J, Gruffydd E, Baron-Cohen S, Smith P, Allison C, Simner J. Savant syndrome has a distinct psychological profile in autism. Mol Autism. 2018 Oct 12;9:53. doi: 10.1186/s13229-018-0237-1. PMID: 30344992; PMCID: PMC6186137.

12. Treffert DA, Christensen DD. Inside the mind of a savant. Sci Am. 2005 Dec;293(6):108-13. doi: 10.1038/scientificamerican1205-108. PMID: 16323698.

13. Hughes JEA, Simner J, Baron-Cohen S, Treffert DA, Ward J. Is Synaesthesia More Prevalent in Autism Spectrum Conditions? Only Where There Is Prodigious Talent. Multisens Res. 2017 Jan 1;30(3-5):391-408. doi: 10.1163/2213480800002558. PMID: 31287074.] 
14. Fujita S. Matrix cells and cytogenesis of the central nervous system. J Comp Neurol. 1963 Feb;120:37-42. doi: 10.1002/cne.901200104. PMID: 13960118.

15. McConell SK. Constructing the cerebral cortex: neurogenesis and fate determination. Neuron. 1995 Oct;15(4):761-8. doi: 10.1016/0896-6273(95)90168-x. PMID: 7576626.

16. Broca P. Remarques sur la siège de la faculté du langue. Bull Soc Anat 1861;6:330-57.

17. Wernicke C. Der aphasische Symptomenkomplex. Breslau: Max Cohn und Weigert, 1874.

18. Atchley RA, Keeney M, Burgess C. Cerebral hemispheric mechanisms linking ambiguous word meaning retrieval and creativity. Brain Cogn. 1999 Aug;40(3):479-99. doi: 10.1006/brcg.1999.1080. PMID: 10415133.

19. Liu SR, Chiarello C, Quan N. Hemispheric sensitivity to grammatical cues: evidence for bilateral processing of number agreement in noun phrases. Brain Lang. 1999 Dec;70(3):483503. doi: 10.1006/brln.1999.2185. PMID: 10600230.

20. Sereno JA. Hemispheric differences in grammatical class. Brain Lang. 1999 Oct 15;70(1):13-28. doi: 10.1006/brln.1999.2137. PMID: 10534370.

21. Crow TJ. Schizophrenia as the price that homo sapiens pays for language: a resolution of the central paradox in the origin of the species. Brain Res Brain Res Rev. 2000 Mar;31(2-3):118-29. doi: 10.1016/s0165-0173(99)00029-6. PMID: 10719140.

22. Tobias PV. The Brain in Hominid Evolution. New York: Columbia University Press, (1971) eBook (DLC) 78158458.

23. Tobias PV. The brain of the first hominids. In JP Changeux and J Chavaillon (editors) Origins of the Human Brain, pp 61-83. Oxford: Oxford University Press, 1995.ISBN 978-0-19852390-1. doi: 10.1093/acprof:oso/9780198523901.001.0001.

24. Flashman LA, McAllister TW, Andreasen NC, Saykin AJ. Smaller brain size associated with unawareness of illness in patients with schizophrenia. Am J Psychiatry. 2000 Jul;157(7):1167-9. doi: 10.1176/appi.ajp.157.7.1167. PMID: 10873930.

25. Vogeley K, Hobson T, Schneider-Axmann T, Honer WG, Bogerts B, Falkai P (1998) Compartmental volumetry of the superior temporal gyrus reveals sex differences in schizophrenia - a post-mortem study. Schizophr Res 31: 83-87. Schizophr Res. 1998 May 25;31(2-3):83-7. doi: 10.1016/s0920-9964(98)00019-x. PMID: 9689712.

26. Bryant NL, Buchanan RW, Vladar K, Breier A, Rothman M (1999) Gender differences in temporal lobe structures of patients with schizophrenia: a volumetric MRI study. Am J Psychiatry 156: 603-609. Am J Psychiatry. 1999 Apr;156(4):603-9. doi: 10.1176/ajp.156.4.603. PMID: 10200741.

27. Harrison PJ. The neuropathology of schizophrenia. A critical review of the data and their interpretation. Brain. 1999 Apr;122 (Pt 4):593-624. doi: 10.1093/brain/122.4.593. PMID: 10219775.

28. Woodruff PW, McManus IC, David AS. Meta-analysis of corpus callosum size in schizophrenia. J Neurol Neurosurg Psychiatry. 1995 Apr;58(4):457-61. doi: 10.1136/jnnp.58.4.457. PMID: 7738554; PMCID: PMC1073433.

29. Downhill JE Jr, Buchsbaum MS, Wei T, Spiegel-Cohen J, Hazlett EA, Haznedar MM, Silverman J, Siever LJ. Shape and size of the corpus callosum in schizophrenia and schizotypal personality disorder. Schizophr Res. 2000 May 5;42(3):193208. doi: 10.1016/s0920-9964(99)00123-1. PMID: 10785578.

30. Plum F (1972) Prospects for research on schizophrenia. 3. Neurophysiology. Neuropathological findings. Neurosci Res Program Bull 1972;10:384-8. PMID: 4663816.

31. Orr KG, Cannon M, Gilvarry CM, Jones PB, Murray RM. Schizophrenic patients and their first-degree relatives show an excess of mixed-handedness. Schizophr Res. 1999 Oct 19;39(3):167-76. doi: 10.1016/s0920-9964(99)00071-7. PMID: 10507509.

32. Crow TJ. The 'big bang' theory of the origin of psychosis and the faculty of language. Schizophr Res. 2008 Jul;102(1-3):3152. doi: 10.1016/j.schres.2008.03.010. Epub 2008 May 23. PMID: 18502103.

33. Hori K, Shimaoka K, Hoshino M. AUTS2 Gene: Keys to Understanding the Pathogenesis of Neurodevelopmental Disorders. Cells. 2021 Dec 21;11(1):11. doi: 10.3390/cells11010011. PMID: 35011572; PMCID: PMC8750789.

34. Schultze-Lutter F, Kindler J, Ambarini TK, Michel C. Positive psychotic symptoms in childhood and adolescence. Curr Opin Psychol. $2021 \quad$ Dec 7; $45: 101287 . \quad$ doi: 10.1016/j.copsyc.2021.11.007. Epub ahead of print. PMID: 35016089.

35. Levinson DF, Holmans P, Straub RE, Owen MJ, Wildenauer DB, Gejman PV, Pulver AE, Laurent C, Kendler KS, Walsh D, Norton N, Williams NM, Schwab SG, Lerer B, Mowry BJ, Sanders AR, Antonarakis SE, Blouin JL, DeLeuze JF, Mallet J. Multicenter linkage study of schizophrenia candidate regions on chromosomes 5q, 6q, 10p, and 13q: schizophrenia linkage collaborative group III. Am J Hum Genet. 2000 Sep;67(3):65263. doi: 10.1086/303041. Epub 2000 Aug 2. PMID: 10924404; PMCID: PMC1287525.

36. Kawanishi Y, Harada S, Tachikawa H, Okubo T, Shiraishi H. Novel polymorphisms of the AP-2 gene (6p24): analysis of association with schizophrenia. J Hum Genet. 2000;45(1):2430. doi: 10.1007/s100380050005. PMID: 10697959.

37. Kendler KS, Myers JM, O'Neill FA, Martin R, Murphy B, MacLean CJ, Walsh D, Straub RE. Clinical features of schizophrenia and linkage to chromosomes 5q, 6p, 8p, and 10p in the Irish Study of High-Density Schizophrenia Families. Am J Psychiatry. $2000 \quad$ Mar;157(3):402-8. doi: 10.1176/appi.ajp.157.3.402. PMID: 10698816.

38. Brzustowicz LM, Hodgkinson KA, Chow EW, Honer WG, Bassett AS. Location of a major susceptibility locus for familial schizophrenia on chromosome 1q21-q22. Science. 2000 Apr 28;288(5466):678-82. doi: 10.1126/science.288.5466.678. PMID: 10784452; PMCID: PMC3787922.

39. Schizophrenia Working Group of the Psychiatric Genomics Consortium. Biological insights from 108 schizophreniaassociated genetic loci. Nature. 2014 Jul 24;511(7510):421-7. 
doi: 10.1038/nature13595. Epub 2014 Jul 22. PMID: 25056061; PMCID: PMC4112379.

40. Crow TJ. Current status of linkage for schizophrenia: polygenes of vanishingly small effect or multiple false positives? Am J Med Genet. 1997 Feb 21;74(1):99-103. PMID: 9034015.

41. Crow TJ. The emperors of the schizophrenia polygene have no clothes. Psychol Med. 2008 Dec;38(12):1681-5. doi: 10.1017/S0033291708003395. Epub 2008 Apr 21. PMID: 18423075 .

42. Richetto J, Meyer U. Epigenetic Modifications in Schizophrenia and Related Disorders: Molecular Scars of Environmental Exposures and Source of Phenotypic Variability. Biol Psychiatry. 2021 Feb 1;89(3):215-226. doi: 10.1016/j.biopsych.2020.03.008. Epub 2020 Mar 28. PMID: 32381277.

43. Maric NP, Svrakic DM. Why schizophrenia genetics needs epigenetics: a review. Psychiatr Danub. 2012 Mar;24(1):2-18. PMID: 22447077.

44. van de Leemput J, Hess JL, Glatt SJ, Tsuang MT. Genetics of Schizophrenia: Historical Insights and Prevailing Evidence. Adv Genet. 2016;96:99-141. doi: 10.1016/bs.adgen.2016.08.001. Epub 2016 Sep 27. PMID: 27968732.

45. Stilo SA, Murray RM. Non-Genetic Factors in Schizophrenia. Curr Psychiatry Rep. 2019 Sep 14;21(10):100. doi: 10.1007/s11920-019-1091-3. PMID: 31522306; PMCID: PMC6745031.

46. Zamanpoor M. Schizophrenia in a genomic era: a review from the pathogenesis, genetic and environmental etiology to diagnosis and treatment insights. Psychiatr Genet. 2020 Feb;30(1):1-9. doi: 10.1097/YPG.0000000000000245. PMID: 31764709.

47. Besteher B, Brambilla P, Nenadić I. Twin studies of brain structure and cognition in schizophrenia. Neurosci Biobehav Rev. $2020 \quad$ Feb;109:103-113. doi: 10.1016/j.neubiorev.2019.12.021. Epub 2019 Dec 13. PMID: 31843545.

48. Laval SH, Dann JC, Butler RJ, Loftus J, Rue J, Leask SJ, Bass N, Comazzi M, Vita A, Nanko S, Shaw S, Peterson P, Shields G, Smith AB, Stewart J, DeLisi LE, Crow TJ. Evidence for linkage to psychosis and cerebral asymmetry (relative hand skill) on the X chromosome. Am J Med Genet. 1998 Sep 7;81(5):420-7. doi: 10.1002/(sici)10968628(19980907)81:5<420::aid-ajmg11>3.0.co;2-e. PMID: 9754628.

49. Huang AS, Rogers BP, Sheffield JM, Vandekar S, Anticevic A, Woodward ND. Characterizing effects of age, sex and psychosis symptoms on thalamocortical functional connectivity in youth. Neuroimage. 2021 Nov;243:118562. doi: 10.1016/j.neuroimage.2021.118562. Epub 2021 Sep 7. PMID: 34506914 .

50. Barajas A, Ochoa S, Obiols JE, Lalucat-Jo L. Gender differences in individuals at high-risk of psychosis: a comprehensive literature review. ScientificWorldJournal. 2015;2015:430735. doi: 10.1155/2015/430735. Epub 2015 Jan 1. PMID: 25685840; PMCID: PMC4312997.
51. Kirschner M, Gerhart J. Evolvability. Proc Natl Acad Sci U S A. 1998 Jul 21;95(15):8420-7. doi: 10.1073/pnas.95.15.8420. PMID: 9671692; PMCID: PMC33871.

52. Callier S, Snapyan M, Le Crom S, Prou D, Vincent JD, Vernier P. Evolution and cell biology of dopamine receptors in vertebrates. Biol Cell. 2003 Oct;95(7):489-502. doi: 10.1016/s0248-4900(03)00089-3. PMID: 14597267.

53. Kesby JP, Eyles DW, McGrath JJ, Scott JG. Dopamine, psychosis and schizophrenia: the widening gap between basic and clinical neuroscience. Transl Psychiatry. 2018 Jan 31;8(1):30. doi: 10.1038/s41398-017-0071-9. PMID: 29382821; PMCID: PMC5802623.

54. Schmack K, Bosc M, Ott T, Sturgill JF, Kepecs A. Striatal dopamine mediates hallucination-like perception in mice. Science. 2021 Apr 2;372(6537):eabf4740. doi: 10.1126/science.abf4740. PMID: 33795430.

55. Stahl SM. Beyond the dopamine hypothesis of schizophrenia to three neural networks of psychosis: dopamine, serotonin, and glutamate. CNS Spectr. 2018 Jun;23(3):187-191. doi: 10.1017/S1092852918001013. PMID: 29954475.

56. Cannon WB. Bodily Changes in Pain, Hunger, Fear and Rage; An Account of Recent Researches into the Function of Emotional Excitement. New York: D. Appleton \& Co., 1915. Pp. $x$ iii +311 .

57. Gray JA (Ed.). The Psychology of Fear and Stress. New York: Cambridge University Press; 1987. viii and 422 pp, ISBN 0521-27098-7.

58. Bracha HS. Freeze, flight, fight, fright, faint: adaptationist perspectives on the acute stress response spectrum. CNS Spectr. 2004 Sep;9(9):679-85. doi: 10.1017/s1092852900001954. PMID: 15337864.

59. Taylor SE, Klein LC, Lewis BP, Gruenewald TL, Gurung RA, Updegraff JA. Biobehavioral responses to stress in females: tend-and-befriend, not fight-or-flight. Psychol Rev. 2000 Jul;107(3):411-29. doi: 10.1037/0033-295x.107.3.411. PMID: 10941275.

60. Liu W, Gu N, Feng G, Li S, Bai S, Zhang J, Shen T, Xue H, Breen G, St Clair D, He L. Tentative association of the serotonin transporter with schizophrenia and unipolar depression but not with bipolar disorder in Han Chinese. Pharmacogenetics. 1999 Aug;9(4):491-5. PMID: 10780268.

61. Heisler LK, Chu HM, Brennan TJ, Danao JA, Bajwa P, Parsons LH, Tecott LH. Elevated anxiety and antidepressant-like responses in serotonin 5-HT $\mathrm{H}_{1 \mathrm{~A}}$ receptor mutant mice. Proc Natl Acad Sci U S A. 1998 Dec 8;95(25):15049-54. doi: 10.1073/pnas.95.25.15049. PMID: 9844013; PMCID: PMC24573.

62. Stork O, Welzl H, Wotjak CT, Hoyer D, Delling M, Cremer H, Schachner M. Anxiety and increased 5-HT1A receptor response in NCAM null mutant mice. J Neurobiol. 1999 Sep 5;40(3):343-55. doi: 10.1002/(sici)10974695(19990905)40:3<343::aid-neu6>3.0.co;2-s. PMID: 10440734 . 
63. Barbeau D, Liang JJ, Robitalille Y, Quirion R, Srivastava LK. Decreased expression of the embryonic form of the neural cell adhesion molecule in schizophrenic brains. Proc Natl Acad Sci U S A. 1995 Mar 28;92(7):2785-9. doi: 10.1073/pnas.92.7.2785. PMID: 7708724; PMCID: PMC42303.

64. American Psychiatric Association. Diagnostic and Statistical Manual of Mental Disorders, Fifth Edition. Arlington, VA: American Psychiatric Publishing, 2013. doi: 10.1176/appi.books.9780890425596.

65. Weinstein S, Graves RE. Are creativity and schizotypy products of a right hemisphere bias? Brain Cogn. 2002 Jun;49(1):138-51. doi: 10.1006/brcg.2001.1493. PMID: 12027399.

66. Lindell AK. On the interrelation between reduced lateralization, schizotypy, and creativity. Front Psychol. 2014 Jul 28;5:813. doi: 10.3389/fpsyg.2014.00813. PMID: 25120516; PMCID: PMC4112911.

67. Hall J. Schizophrenia - an anxiety disorder? Br J Psychiatry. 2017 Nov;211(5):262-263. doi: 10.1192/bjp.bp.116.195370. PMID: 29092833.

68. Prideaux S. Edvard Munch: Behind the Scream. New Haven:Yale University Press, 2005. ISBN: 13: 9780300110241.

69. Azeem H. The art of Edvard Munch: a window onto a mind. BJPsych Advances 2015;21:51-53 doi: 10.1192/apt.bp.114.012963.

70. Blumer D. The illness of Vincent van Gogh. Am J Psychiatry. 2002 Apr;159(4):519-26. doi: 10.1176/appi.ajp.159.4.519. PMID: 11925286.

71. Hemphill RE. The illness of Vincent Van Gogh. Proc R Soc Med. 1961 Dec;54(12):1083-8. PMID: 13906376; PMCID: PMC1870504.

72. Lombroso C. Genio e follia. Seconda edizione completamente rifusa ed ampliata. Milano: Gaetano Brigola, 1872.

73. Stork O, Welzl H, Wotjak CT, Hoyer D, Delling M, Cremer H, Schachner M. Anxiety and increased 5-HT1A receptor response in NCAM null mutant mice. J Neurobiol. 1999 Sep 5;40(3):343-55. doi: 10.1002/(sici)10974695(19990905)40:3<343::aid-neu6>3.0.co;2-s. PMID: 10440734.

74. Stork O, Welzl H, Wolfer D, Schuster T, Mantei N, Stork S, Hoyer D, Lipp H, Obata K, Schachner M. Recovery of emotional behaviour in neural cell adhesion molecule (NCAM) null mutant mice through transgenic expression of NCAM180. Eur J Neurosci. 2000 Sep;12(9):3291-306. doi: 10.1046/j.14609568.2000.00197.x. PMID: 10998113.

75. Wood GK, Tomasiewicz H, Rutishauser U, Magnuson T, Quirion R, Rochford J, Srivastava LK. NCAM-180 knockout mice display increased lateral ventricle size and reduced prepulse inhibition of startle. Neuroreport. 1998 Feb 16;9(3):461-6. doi: 10.1097/00001756-199802160-00019. PMID: 9512390.

76. Barbeau D, Liang JJ, Robitalille Y, Quirion R, Srivastava LK. Decreased expression of the embryonic form of the neural cell adhesion molecule in schizophrenic brains. Proc Natl Acad Sci U S A. 1995 Mar 28;92(7):2785-9. doi: 10.1073/pnas.92.7.2785. PMID: 7708724; PMCID: PMC42303.

77. Vawter MP, Frye MA, Hemperly JJ, VanderPutten DM, Usen N, Doherty P, Saffell JL, Issa F, Post RM, Wyatt RJ, Freed WJ. Elevated concentration of N-CAM VASE isoforms in schizophrenia. J Psychiatr Res. 2000 Jan-Feb;34(1):25-34. doi: 10.1016/s0022-3956(99)00026-6. PMID: 10696830.

78. Bayliss WM, Starling EH. The mechanism of pancreatic secretion. J Physiol. 1902 Sep 12;28(5):325-53. doi: 10.1113/jphysiol.1902.sp000920. PMID: 16992627; PMCID: PMC1540572.

79. Ratzenhofer M, Köle W, Walter GF. Vegetative neurodystonia - search for pathophysiological and morphological data is urgent. In: Ratzenhofer M, Höfler H, Walter GF (Eds.) Interdisciplinary Neuroendocrinology. Frontiers of Hormone Research 1984;12:129-135. Basel: Karger. ISBN 3-8055-38049.

80. Russo AF. Overview of Neuropeptides: Awakening the Senses? Headache. 2017 May;57 Suppl 2(Suppl 2):37-46. doi: 10.1111/head.13084. PMID: 28485842; PMCID: PMC5424629.

81. Cryan JF, O'Riordan KJ, Cowan CSM, Sandhu KV, Bastiaanssen TFS, Boehme M, Codagnone MG, Cussotto S, Fulling C, Golubeva AV, Guzzetta KE, Jaggar M, Long-Smith CM, Lyte JM, Martin JA, Molinero-Perez A, Moloney G, Morelli E, Morillas E, O'Connor R, Cruz-Pereira JS, Peterson VL, Rea K, Ritz NL, Sherwin E, Spichak S, Teichman EM, van de Wouw M, Ventura-Silva AP, Wallace-Fitzsimons SE, Hyland N, Clarke G, Dinan TG. The Microbiota-Gut-Brain Axis. Physiol Rev. 2019 Oct 1;99(4):1877-2013. doi: 10.1152/physrev.00018.2018. PMID: 31460832.

82. Holzer P. Neuropeptides, Microbiota, and Behavior. Int Rev Neurobiol. 2016;131:67-89. doi: 10.1016/bs.irn.2016.08.005. Epub 2016 Sep 14. PMID: 27793227.

83. Holingue C, Budavari AC, Rodriguez KM, Zisman CR, Windheim G, Fallin MD. Sex Differences in the Gut-Brain Axis: Implications for Mental Health. Curr Psychiatry Rep. 2020 Nov 20;22(12):83. doi: 10.1007/s11920-020-01202-y. PMID: 33216233; PMCID: PMC7717677.

84. Petra AI, Panagiotidou S, Hatziagelaki E, Stewart JM, Conti P, Theoharides TC. Gut-Microbiota-Brain Axis and Its Effect on Neuropsychiatric Disorders With Suspected Immune Dysregulation. Clin Ther. 2015 May 1;37(5):984-95. doi: 10.1016/j.clinthera.2015.04.002. PMID: 26046241; PMCID: PMC4458706.

85. Tomasik J, Rahmoune H, Guest PC, Bahn S. Neuroimmune biomarkers in schizophrenia. Schizophr Res. 2016 Sep;176(1):3-13. doi: 10.1016/j.schres.2014.07.025. Epub 2014 Aug 12. PMID: 25124519.

86. Buckley PF. Neuroinflammation and Schizophrenia. Curr Psychiatry Rep. 2019 Jul 3;21(8):72. doi: 10.1007/s11920-0191050-z. PMID: 31267432.

87. Yehuda R, Brand S, Yang RK. Plasma neuropeptide Y concentrations in combat exposed veterans: relationship to trauma exposure, recovery from PTSD, and coping. Biol Psychiatry. 2006 Apr 1;59(7):660-3. doi: 
10.1016/j.biopsych.2005.08.027. Epub 2005 Dec 1. PMID: 16325152.

88. Dumont Y, Quirion R. Neuropeptide Y pathways in anxietyrelated disorders. Biol Psychiatry. 2014 Dec 1;76(11):834-5. doi: 10.1016/j.biopsych.2014.09.015. Epub 2014 Nov 4. PMID: 25439997.
89. Reichmann F, Holzer P. Neuropeptide Y: A stressful review. Neuropeptides. 2016 Feb;55:99-109. doi: 10.1016/j.npep.2015.09.008. Epub 2015 Sep 30. PMID: 26441327; PMCID: PMC4830398.

90. Kraepelin E. Einführung in die Psychiatrische Klinik. Band 1, 4. Auflage, p.67. Leipzig: Johann Ambrosius Barth, 1921.
This work is licensed under Creative Commons Attribution 4.0 License
Ready to submit your research? Choose Auctores and benefit from:

$>$ fast, convenient online submission

$>$ rigorous peer review by experienced research in your field

$>$ rapid publication on acceptance

$>$ authors retain copyrights

$>$ unique DOI for all articles

$>$ immediate, unrestricted online access

At Auctores, research is always in progress.

Learn more https://auctoresonline.org/journals/neuroscience-and-neurologicalsurgery 